\title{
EVALUATION OF THE ABO BLOOD GROUP DISTRIBUTION IN SERBIAN PATIENTS WITH DIABETES MELLITUS TYPE 2
}

\author{
Ivana Kucevic ${ }^{1}$, Jelena Vasic ${ }^{2}$, Jelena Zvekic Svorcan ${ }^{3,4}$, Brankica Radisic ${ }^{5}$ \\ ${ }^{1}$ Faculty of Medical Sciences, University of Kragujevac, Kragujevac, Serbia \\ ${ }^{2}$ Department of Public Health "Serbian Railways", Belgrade, Serbia \\ ${ }^{3}$ Special Hospital for Rheumatic Diseases, Novi Sad, Serbia \\ ${ }^{4}$ Medical Faculty, University of Novi Sad, Novi Sad, Serbia \\ ${ }^{5}$ Aleksandar MN, Belgrade, Serbia
}

\author{
ANALIZA DISTRIBUCIJE IRVNIH GRUPA PREMA ABO SISTEMU KOD \\ PACIJENATA OBOLELIH OD DIJABETES MELITUSA TIP 2 U SRBIJI

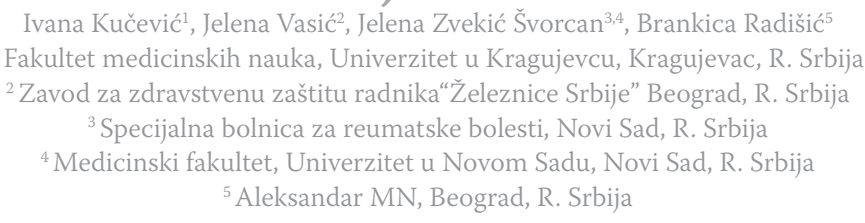

Received / Primljen: 17.07.2013.

\begin{abstract}
The aim of our study was to evaluate the distribution of the ABO blood groups in sample of Serbian patients diagnosed with diabetes mellitus type 2. We evaluated 114 patients from Serbia that were diagnosed with diabetes mellitus type 2. All ABO blood groups were recorded as well as the $\mathrm{HbA} / 1-\mathrm{C}$ values in each patient. We also analysed the presence of the following risk factors: positive family history, elevated triglycerides, increased blood pressure and overweight. Male and female patients were evaluated separately. The most frequent blood type in this group of patients was the A blood group, whereas the least frequent was the $A B$ blood group. There was a significant increase in the frequency of the AB blood group in Serbian patients with $D M$ type 2 compared to the frequency in the overall Serbian population $(p<0.05)$, whereas no significant differences were observed for the other blood groups within the ABO system. An increase in the distribution of the $A B$ blood group was observed in patients with increased levels of $H b A 1 C$, although this increase was not significant. The highest proportion of evaluated risk factors was observed in patients belonging to the O blood group, whereas the lowest proportion was in patients belonging to the A blood group (n.s.). The results of this study suggest a possible trend between the $A B O$ blood groups and the risk of diabetes mellitus type 2 as well as a correlation between the $A B O$ blood groups and riskfactors in patients diagnosed with diabetes mellitus type 2. Therefore, a larger cohort study is needed to better define the initial observations based on our results.
\end{abstract}

Key words: $A B O$ blood groups, diabetes mellitus type 2 , gender, risk factors

\section{SAŽETAK}

Cilj rada je bio da se ispita distribucija $A B O$ krvnih grupa u uzorku pacijenata sa dijagnostikovanim dijabetes melitusom tip 2 iz Srbije. Analizirana su 114 pacijenata iz Srbije kod kojih je dijagnostikovan dijabetes melitus tip 2. Ispitivane su sve krvne grupe iz ABO sistema krvnih grupa, kao $i$ vrednosti HbA/1-C. Prisustvo sledecih riziko faktora je praćeno: pozitivna porodična istorija, povišeni trigliceridi, povišen krvni pritisak i prekomerna telesna težina. Zasebno su analizirani muški $i$ ženski pol. Najčešće zastupljeni tip krvne grupe kod ispitivanih pacijenata je A, dok je AB najređe bila zastupljena. Postoji statistički značajno povećanje u zastupljenosti AB krvne grupe kod ispitivanih pacijenata u odnosu na učestalost u Srpskoj populaciji $(p<0.05)$, dok za ostale krvne grupe nije uočena statistički značajana razlika. Povećana zastupljenost AB krvne grupe (mada ne značajno) je primećena kod pacijenata sa povišenim vrednostima HbA1C. Najviše riziko faktora je bilo kod ispitivanih pacijenata sa O krvnom grupom, dok je najmanje riziko faktora bilo kod pacijenata sa A krvnom grupom ali bez statističke značajnosti. Rezultati ove studije mogu biti pokazatelji inicijalnog trenda potencijalne korelacije izmedu $A B O$ sistema krvnih grupa i dijabetes melitus tipa 2 kao $i$ korelacije $A B O$ sistema krvnih grupa i riziko faktora kod ispitiavnih pacijenata sa dijabetes meliusom tip 2. Stoga su neophodna dalja istraživanja na većem uzorku pacijenata.

Ključne reči: $A B O$ krvne grupe, dijabetes mellitus tip 2, pol, faktori rizika

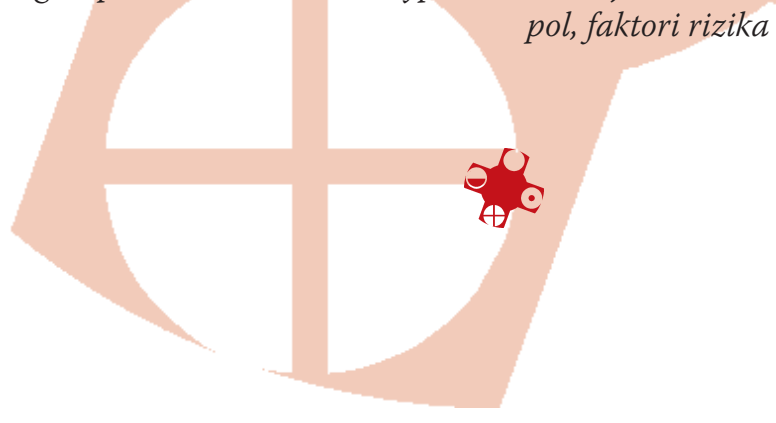

UDK: 616.379-008.64:612.118 / Ser J Exp Clin Res 2013; 14 (3): 109-112 DOI: 10.5937/SJECR14-4214 


\section{INTRODUCTION}

Diabetes mellitus (DM) type 2 is an emerging problem worldwide and is ultimately leads to an increase in cardiovascular morbidity and mortality (1). It is estimated that 50 million adults in the United States will be diagnosed with DM type 2 by $2050(1,2)$. The exact etiology of DM type 2 is unknown, but multifactorial inheritance has been suggested in numerous studies $(3,4)$. In the work of Bastard et al., it was postulated that the risk factor obesity could be associated with inflammation to a certain degree, which might lead to the impaired glucose tolerance and eventually develop into DM (5). Previous reports have demonstrated correlation between infections and various tumors with certain types of ABO blood groups (6-8). Therefore, we hypothesised that Serbian patients with DM type 2 along with a presence of several risk factors could have a unique distribution of the $\mathrm{ABO}$ blood groups compared to the Serbian population. Thus, the aim of our study was to evaluate the distribution of the $\mathrm{ABO}$ blood groups in sample of Serbian patients with diagnosed DM type 2.

\section{MATERIAL AND METHODS}

\section{Study group}

We evaluated 114 patients from Serbia who were diagnosed with diabetes mellitus type 2 . Prior to inclusion, eligible participants were informed about study protocol and provided consent. The study followed the principles of good clinical practice. The patients were age between $50-65$ years of age, with 35 (56.5\%) males and 27 (43.5\%) females .

Blood samples were drawn from the patients to establish the $\mathrm{ABO}$ blood type into one of the following groups:: $\mathrm{A}, \mathrm{B}, \mathrm{AB}$ and $\mathrm{O}$. The established distributions were compared with the distributions of the ABO blood groups within the Serbian population (9).

The risk factors of positive family history and elevated triglycerides were gathered from the patients' records and anamnesis, whereas increased blood pressure and obesity were assessed during the study. Additionally, the frequencies of the $\mathrm{ABO}$ blood groups were analysed in patients with increased $\mathrm{HbA1C}$. Increased blood pressure values were defined above $90^{\text {th }}$ percentile based on the age, gender and height of the patient (10), whereas excessive weight and obesity was determined based on the body mass index (BMI) and adjusted to age and gender.

\section{Statistical analysis}

The ABO blood group distribution values are presented as whole numbers and percentages. The frequencies of the risk factors for each blood group from the ABO blood group system are presented as the mean values with standard deviation (SD). For evaluation of the statistical significance between the distributions of $\mathrm{ABO}$ blood groups in different samples, we used the Chi squared test. Unifactorial ANOVA was used for statistical interpretation of the evaluated risk factors frequencies between the different $\mathrm{ABO}$ blood groups. The results were considered to be statistically significant when $\mathrm{p}<0.05$.

\section{RESULTS}

The most frequent blood group in the evaluated patients was the A blood group (38.7\%), whereas the least frequent was the AB blood group (12.9\%) (Table 1). Regarding gender, the most frequent blood group in males was the A blood group (42.9\%), and the least frequent was the $A B$ blood group (14.3\%). However, females showed a similar distribution of the A and O blood groups (33.3\%) (Table 1). For individuals with increased $\mathrm{HbA1C}$ levels, the most frequent blood group was the A blood group (40.5\%), and the least frequent was the $A B$ blood group (11.9\%) (Table 1). The highest proportion of evaluated risk factors was observed in patients with type O blood $(2.61 \pm 0.85)$, whereas the lowest proportion was observed in patients with type A blood (2.33 \pm 1.01$)$ (Table 1).

\begin{tabular}{|c|c|c|c|c|c|c|}
\hline \multirow[b]{2}{*}{ Blood groups } & \multirow{2}{*}{$\begin{array}{l}\text { Serbian } \\
\text { population } \\
\text { (ref.9) }\end{array}$} & \multirow[b]{2}{*}{$\begin{array}{l}\text { Patients } \\
\text { N (\%) }\end{array}$} & \multicolumn{2}{|c|}{ Patients (gender) } & \multirow{2}{*}{$\begin{array}{l}\text { Increased } \\
\text { HbA1C } \\
\text { N (\%) }\end{array}$} & \multirow{2}{*}{$\begin{array}{l}\text { Risk factor } \\
\mathrm{MV} \pm \mathrm{SD}\end{array}$} \\
\hline & & & $\begin{array}{l}\text { Males } \\
\text { N (\%) }\end{array}$ & \begin{tabular}{|l|} 
Females \\
N (\%)
\end{tabular} & & \\
\hline A & $\begin{array}{l}71953 \\
(41.5) \\
\end{array}$ & \begin{tabular}{|l}
44 \\
$(38.7)$ \\
\end{tabular} & $\begin{array}{l}28 \\
(42.9) \\
\end{array}$ & \begin{tabular}{|l}
17 \\
$(33.3)$ \\
\end{tabular} & $\begin{array}{l}17 \\
(40.5) \\
\end{array}$ & $2.33 \pm 1.01$ \\
\hline B & $\begin{array}{l}30341 \\
(17.5) \\
\end{array}$ & \begin{tabular}{|l|}
22 \\
$(19.4)$ \\
\end{tabular} & $\begin{array}{l}11 \\
(17.1) \\
\end{array}$ & \begin{tabular}{|l}
11 \\
$(22.2)$ \\
\end{tabular} & \begin{tabular}{|l}
6 \\
$(14.3)$ \\
\end{tabular} & $2.50 \pm 0.90$ \\
\hline $\mathrm{AB}$ & $\begin{array}{l}12310 \\
(7.1) \\
\end{array}$ & \begin{tabular}{|l}
14 \\
$(12.9)$ \\
\end{tabular} & $\begin{array}{l}9 \\
(14.3) \\
\end{array}$ & \begin{tabular}{|l}
7 \\
$(11.1)$ \\
\end{tabular} & \begin{tabular}{|l}
5 \\
$(11.9)$ \\
\end{tabular} & $2.50 \pm 0.93$ \\
\hline $\mathrm{O}$ & $\begin{array}{l}58776 \\
(33.9)\end{array}$ & $\begin{array}{l}34 \\
(29.0)\end{array}$ & $\begin{array}{l}17 \\
(25.7)\end{array}$ & $\begin{array}{l}17 \\
(33.3)\end{array}$ & \begin{tabular}{|l}
14 \\
$(33.3)$
\end{tabular} & $2.61 \pm 0.85$ \\
\hline Total & 173380 & 114 & 65 & 52 & 42 & - \\
\hline
\end{tabular}

Table 1. Distribution of ABO blood groups in patients with DM type 2 


\begin{tabular}{|c|c|c|c|c|}
\hline \multirow{2}{*}{ Blood groups } & \multicolumn{3}{|c|}{$\begin{array}{c}\text { Chi squared test } \\
\text { (p values) }\end{array}$} & $\begin{array}{c}\text { ANOVA } \\
\text { (p values) }\end{array}$ \\
\cline { 2 - 4 } & $\begin{array}{c}\text { Serbian population } \\
\text { vs. patients }\end{array}$ & $\begin{array}{c}\text { Serbian population } \\
\text { vs. individuals with } \\
\text { increased HbA1C }\end{array}$ & Males vs. females & \multirow{2}{*}{ Risk factors } \\
\hline $\mathrm{A}$ & $>0.05$ & $>0.05$ & $>0.05$ & \multirow{2}{*}{$>0.05$} \\
\hline $\mathrm{B}$ & $>0.05$ & $>0.05$ & $>0.05$ & \\
\hline $\mathrm{AB}$ & $<0.05$ & $>0.05$ & $>0.05$ & \\
\hline $\mathrm{O}$ & $>0.05$ & $>0.05$ & $>0.05$ & \\
\hline
\end{tabular}

Table 2. Statistical interpretation of the ABO blood group distribution between study individuals

We observed a significant increase in the frequency of the AB blood group in Serbian patients with DM type 2 compared with the frequency in the Serbian population $(p<0.05)$ whereas the increase in the distribution of the $A B$ blood group in patients with increased $\mathrm{HbA1C}$ was not significant. For the frequencies of the other blood groups within the ABO system, we observed no significant differences (Table 2). There was an insignificant difference in the mean values of the risk factor frequencies between the patients with different $\mathrm{ABO}$ blood groups (Table 2).

In comparing the frequency of the 4 risk factors selected within each $\mathrm{ABO}$ blood group, we observed that the existence of 3 risk factors was most common for all of the blood groups (A blood group: 41.7\%; B blood group: 50.0\%; O blood group: $50.0 \%$ ), except for patients in the $A B$ blood group, in which having either 2 or 3 risk factors occurred at similar frequencies (37.5\%) (Graph 1).

\section{DISCUSSION}

Previous reports have shown that different ABO blood groups are more frequent in patients with various pathological conditions (e.g., different types of cancers, infections, etc.) (11-13). In a couple of studies performed by Serbian researchers, it was reported that the frequency of the A blood group is significantly increased in individuals with congenital hip dislocation, whereas patients suffering from tuberculosis infection were more likely to belong to the O blood group $(14,15)$.

The results of our study showed that Serbian individuals with type $\mathrm{AB}$ blood are more prone to possibly developing DM type 2 during one's lifetime compared to the overall Serbian population (9). This finding was accompanied with an increased (albeit insignificant) frequency of the $\mathrm{AB}$ blood group in patients with increased HbA1C levels, which can be useful for more complete analysis of obtained result. Kamil et al. (15) reported that there was no significant correlation for any of the $\mathrm{ABO}$ blood groups between patients with DM type 2 and controls. Similar results were observed by Cvjeticanin et al. in Serbian individuals (white population) with DM (14). However, the difference in the frequencies for different $\mathrm{ABO}$ blood types between various races and ethnic groups might explain to a certain degree the distinction of the $\mathrm{AB}$ blood group frequency between Serbian patients with DM type 2 versus the $A B$ blood group frequency in the Serbian population (16). In support of the possible role of blood groups in the susceptibility for developing DM type 2, Nemesure et al. showed that Rhesus $\mathrm{C}+$ antigen decreases the likelihood for developing DM type 2 (17).

Regarding the possible role of gender and $\mathrm{ABO}$ blood type in the development of DM type 2, we observed that despite the lack of any significant difference in the dis-

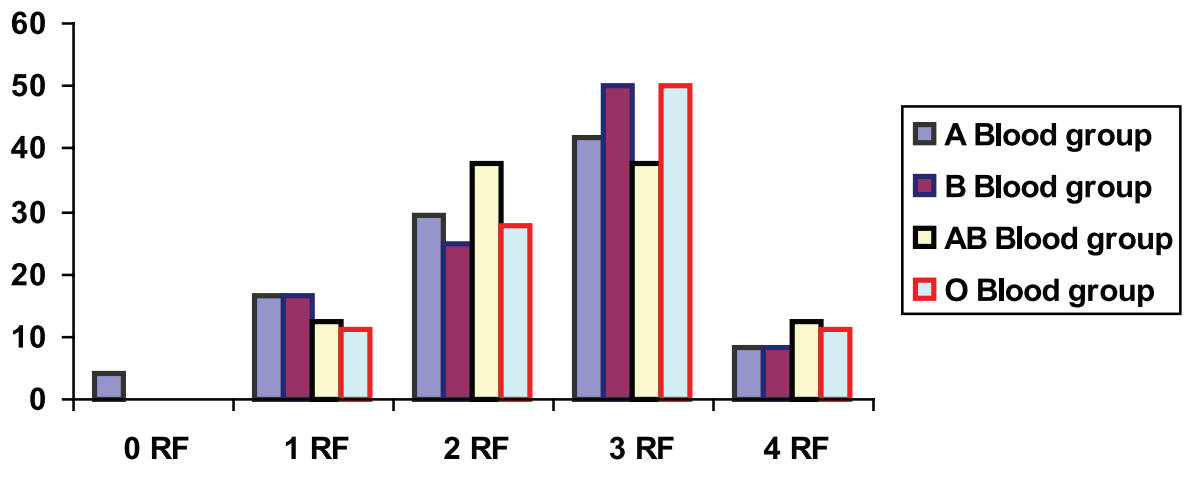

Graph 1. Frequency of multiple risk factors within the $\mathrm{ABO}$ blood groups 
tribution of the $\mathrm{ABO}$ blood groups between genders, the A blood group was more frequent in males, whereas the O blood group was more frequent in females. These initial findings suggest to a certain degree a possible correlation between gender and $\mathrm{ABO}$ blood groups in the development of DM type 2. However, it should be noted out that additional studies are needed to investigate this correlation.

We have demonstrated (Table 1) that, for the patients with DM type 2 from this study, individuals in the O blood group have the highest number of evaluated risk factors, whereas those in the A blood group have the lowest number of evaluated risk factors, despite a lack of significance. These could imply to the assumption that individuals with DM type 2 and having type A blood are less sensitive to the possible influence of the evaluated risk factors, whereas those in the $\mathrm{O}$ blood group might be more sensitive. As shown in Graph 1, the patients with DM type 2 with a different number of risk factors have different frequencies within the ABO blood groups. These differences suggest the presence of possible predispositions for development of DM type 2 in individuals with varying numbers of risk factors and belonging to different $\mathrm{ABO}$ blood groups.

Although this was one of the first reports that focused on the influence of $\mathrm{ABO}$ blood groups, risk factors and gender on the probability of developing DM type 2 further studies with a larger cohort patient population are needed to confirm these results. However, our results could lead to more complex and broader investigations concerning the possible association between ABO blood groups and DM type 2, as well as correlation between ABO blood groups and risk factors in patients diagnosed with DM type 2.

\section{REFERENCES:}

1. Chhabra L, Liti B, Kuraganti G, Kaul S, Trivedi N.Challenges in the management of type 2 diabetes mellitus and cardiovascular risk factors in obese subjects: what is the evidence and what are the myths? Int J Endocrinol. 2013;2013:856793.

2. Boyle JP, Thompson TJ, Gregg EW, Barker LE, Williamson DF. Projection of the year 2050 burden of diabetes in the US adult population: dynamic modeling of incidence, mortality, and prediabetes prevalence. Population Health Metrics 2010;8:29.

3. El Ela MH, Azeem AA, Elbastawisy HI, Osman ZM. Population genetic study of diabetes and diabetic retinopathy among Egyptians. Bratisl Lek Listy. 2012;113(10):595-598.
4. Mandrup-Poulsen T. Type 2 diabetes mellitus: a metabolic autoinflammatory disease. Dermatol Clin. 2013;31(3):495-506.

5. Bastard JP, Maachi M, Lagathu C, Kim MJ, Caron M, Vidal H, Capeau J, Feve B. Recent advances in the relationship between obesity, inflammation, and insulin resistance. Eur Cytokine Netw. 2006;17(1):4-12.

6. Jaff MS. Relation between ABO blood groups and Helicobacter pylori infection in symptomatic patients. Clin Exp Gastroenterol. 2011;4:221-226.

7. Roberts JA. Blood groups and susceptibility to disease: a review. Br J Prev Soc Med. 1957;11:107-125.

8. Greer JB, Yazer MH, Raval JS, Barmada MM, Brand RE, Whitcomb DC. Significant association between ABO blood group and pancreatic cancer. World J Gastroenterol. 2010;16:5588-5591.

9. Savic S. PhD thesis. Serbia: School of Medicine, University of Belgrade; 1994. Immunological characteristics of ABO blood group system.

10. National Blood Pressure Education Program Working group on High Blood Pressure in Children and Adolescents. The fourth report on the diagnosis, evaluation, and treatment of high blood pressure in children and adolescents. Pediatrics 2004;114(2 suppl $4^{\text {th }}$ Report):555-576.

11. Gong Y, Yang YS, Zhang XM, Su M, Wang J, Han JD, Guo MZ.ABO blood type, diabetes and risk of gastrointestinal cancer in northern China. World J Gastroenterol. 2012;18(6):563-956.

12. Vioque J, Walker AM. Pancreatic cancer and ABO blood types: a study of cases and controls. Med Clin (Barc) 1991;96:761-764.

13. Shavakhi A, Hajalikhani M, Minakari M, Norian A, Riahi R, Azarnia M, Liaghat L.The association of non-O blood group and severity of liver fibrosis in patients with chronic hepatitis C infection. J Res Med Sci. 2012;17(5):466-9.

14. Cvjeticanin S, Marinkovic D. Genetic variability in the group of patients with congenital hip dislocation. Genetika 2005;41(8):1142-1146.

15. Kamil M, Al-Jamal HA, Yusoff NM. Association of ABO blood groups with diabetes mellitus. Libyan J Med. 2010;5: 10.3402/ljm.v5i0.4847.

16. Garratty G, Glynn SA, McEntire R; Retrovirus Epidemiology Donor Study. ABO and Rh(D) phenotype frequencies of different racial/ethnic groups in the United States. Transfusion 2004;44(5):703-6.

17. Nemesure B, Wu SY, Hennis A, Leske MC; Barbados Eye Study Group.Hypertension, type 2 diabetes, and blood groups in a population of African ancestry. Ethn Dis 2006;16(4):822-829. 